\title{
Periosteoplasty for covering gingival recessions: Clinical results
}

\author{
Sascha Virnik' \\ Friedrich Michael Chiari' \\ Alexander Gaggl ${ }^{2}$ \\ 'Department of Oral and Maxillofacial \\ Surgery, Central Hospital/LKH, \\ Klagenfurt, Austria; ${ }^{2}$ Centre \\ of Maxillofacial Surgery, "Pyramide \\ am See" Clinic, Zurich, Switzerland
}

Correspondence: Sascha Virnik, Department of Oral and Maxillofacial Surgery Central Hospital/LKH Klagenfurt St Veiterstr. 47 A-9020 Klagenfurt, Austria

Tel +4346353822421

Fax +434635382206I

Email andreas.virnik@lkh-klu.at

\begin{abstract}
This is a case series in which a new technique for the surgical treatment of periodontal recessions is presented along with the results of the first clinical trial. A new technique of periodontal flap surgery was performed on 30 patients with severe periodontal recessions of the upper or lower front teeth. Root and soft tissue scaling was carried out with an open approach, then the periosteum was incised and mobilized at the apical part of the mucoperiosteum flap to cover the defect before the mucoperiosteum was reattached and fixed by sutures. Sulcus bleeding, periodontal probing depths, attachment loss and the length of the attached gingiva of the affected teeth were recorded preoperatively and at 3, 6, and 12 months postoperatively. Every clinical parameter was improved by surgery. No sulcus bleeding was observed at any time during the postoperative follow-up. A mean reattachment of $5.5 \mathrm{~mm}$ was noticed 12 months postoperatively at a mean probing depth of $0.3 \mathrm{~mm}$. The mean height of the attached gingiva was $0 \mathrm{~mm}$ before surgery, $2.3 \mathrm{~mm}$ at three and six months postoperatively, and $2.2 \mathrm{~mm}$ at 12 months. The periosteum eversion technique is suitable for the treatment of gingival recessions resulting in good gingival function and a clear improvement in aesthetics.
\end{abstract}

Keywords: periosteoplasty, periodontal surgery, gingival recession

\section{Introduction}

The main aim of periodontal surgery is to achieve a good function of the periodontium and an aesthetically satisfying gingiva. Over the past few years surgical techniques have improved and some new techniques for achieving better results have been described. These techniques are based on the transplantation of free tissue grafts ${ }^{1-4}$ or the application of membranes, ${ }^{5-10}$ the transposition of periodontal flaps, ${ }^{11-19}$ or a combination of both techniques. ${ }^{20-23}$ The rate of success has increased continuously and individualized techniques for achieving the best results in different kinds of recessions have been presented. The morphology of the recession dictates the best technique for root coverage which in turn leads to the best clinical results. The aim is to achieve long-term coverage of the root surface with attached gingiva of normal height and in the correct position. The gingival margin as well as the color and texture of tissue should resemble that of the healthy neighbouring teeth. In other words, the scars of the surgery should not be visible.

To gain an objective assessment of the clinical results, the percentage of root coverage should be ascertained. ${ }^{21,24-29}$ Clinical success depends on the extent of biological regeneration. ${ }^{30-32}$ Complete biological regeneration is only seen in the apical and lateral part of the former recession in this case, while a long epithelial attachment is seen in the other parts of the root when conventional surgical techniques are used. ${ }^{30,33}$

This biological examination requires histological specimens that should only be taken during second-look surgery so as to avoid further periodontal damage in a patient who 
is likely to have a good result. An important parameter for judging the success of a new surgical technique is good clinical results.

Therefore, it can be stated that the best clinical results for covering extended denuded root surfaces are achieved by surgical techniques using a free soft tissue graft but this results in donor-site morbidity. ${ }^{33}$

To avoid donor site-related problems on the one hand and to exploit the advantages of a connective tissue graft on the other, a new surgical technique for root coverage has been developed over the last few years. The technique is based on transposition of the local periosteum in combination with a mucoperiosteum transpositional flap.

Herein, the new periosteum eversion technique used in this study is described and a report on the first clinical trial is presented.

\section{Patients and methods}

Periodontal recessions of the upper or lower front teeth were to be covered surgically in 30 patients. The mean age of patients was 29 years (17-52 years). The periodontal defects were all located at the upper or lower canines in six and four patients and the upper or lower incisors in eight and 12 patients, respectively. Miller class I defects were registered in 10 patients, Miller class II defects in seven patients, and Miller class III defects in 13 patients. ${ }^{34}$ A periodontal probe (PCP12) was used by one examiner.

The depth of recession was between 4 and $8 \mathrm{~mm}$. An intensive oral hygiene program was carried out in the first stage of treatment to reduce preoperative plaque contamination to less than $30 \%$ all over the dentition which is a precondition for surgery. ${ }^{35}$

Three months after achieving an approximal plaque index value of less than $30 \%$, the preoperative findings of the periodontal area and the teeth which were to be treated surgically were recorded. Periodontal bleeding after mild probing, attachment loss, and the height of the attached gingiva were recorded. The loss of periodontal attachment was identified at three different locations for each root, namely mesially, centrally, and distally at the labial root surface (Figure 1) and the highest value of attachment loss was noted. The width of the keratinized gingiva was measured at the same positions as the attachment loss after retracting the lip manually and the lowest value was recorded. Then the root surface was examined for visible plaque contamination which would preclude surgery.

No plaque contamination was seen before surgery, whereas some gingival bleeding was seen preoperatively in nine patients. The new technique of periosteoplasty was then used for every patient (Figures 2a, 2b, 2c, 2d, 2e).

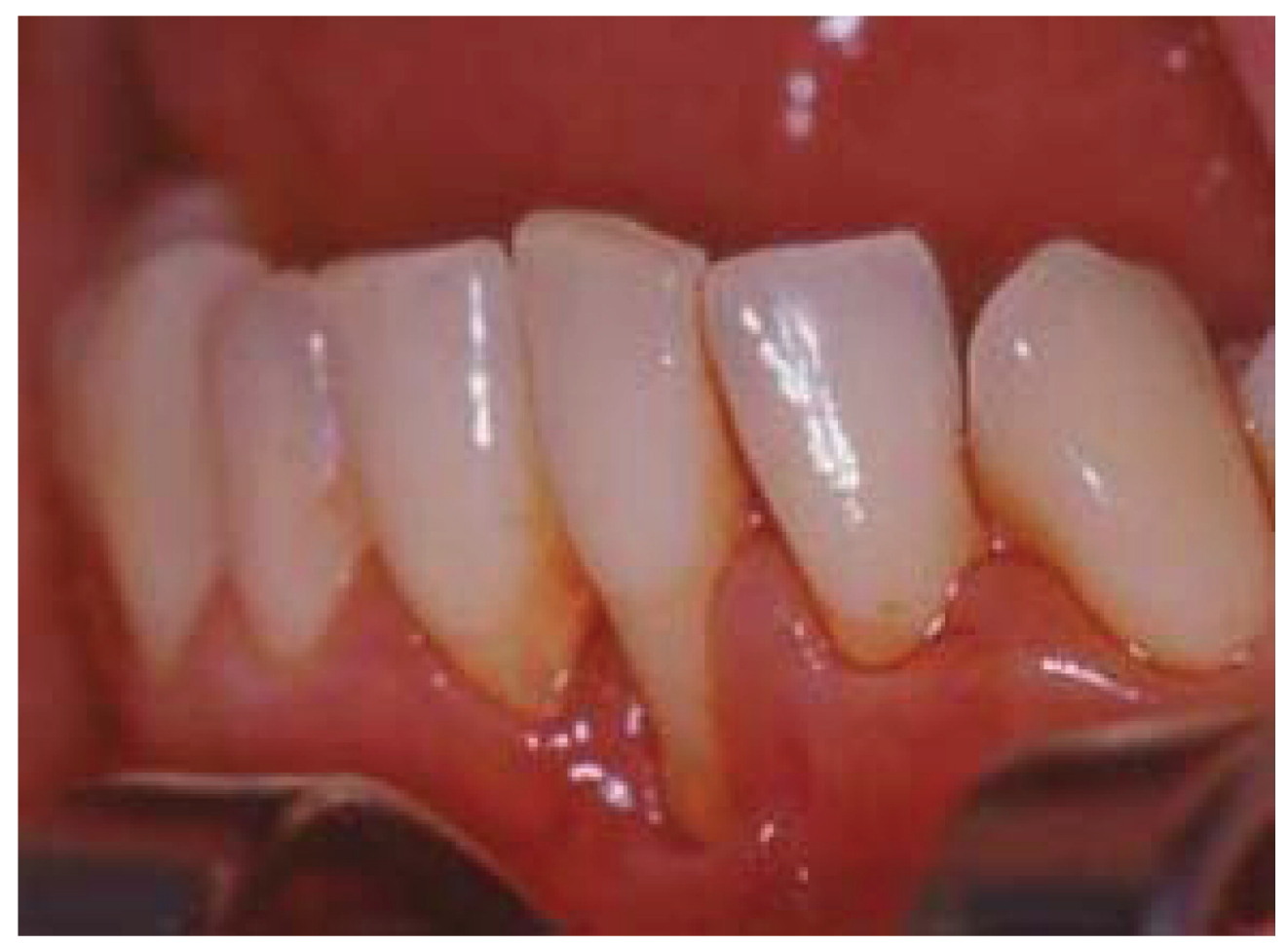

Figure I Loss of peridontal attachment at the root. 

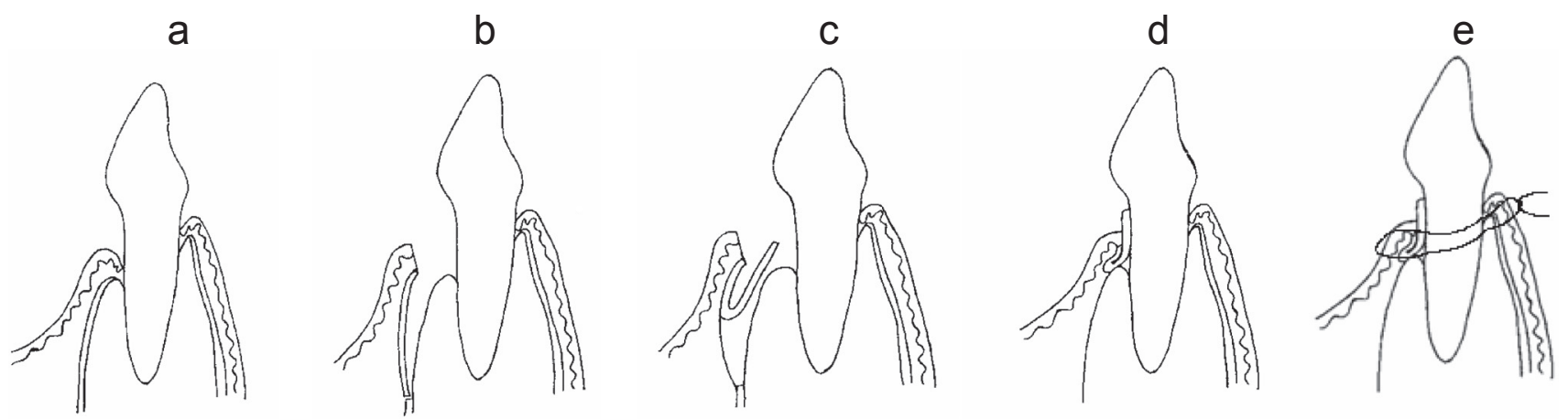

Figure 2 Steps in the new technique of periosteoplasty. a) originally recession; b) mucoperiosteum flap; c) basal incision with everted periosteum; d) placed periosteum; e) coronal transpostion of the mucoperiosteum with intedental stitches.

Surgery was performed under local anesthetic. After marginal incision and lateral vertical incision, a mucoperiosteum flap was deflected. The root surface was cleaned mechanically by scaling and disinfected with chlorhexidine solution (Chlorhexamed ${ }^{\circledR}$ 0.06\%, Blend-a-dent; Proctor \& Gamble, Schwalbach, Germany). The root surface was then conditioned with $40 \%$ acetic acid solution for $20 \mathrm{~s}$ and washed with physiologic saline solution for $60 \mathrm{~s}$ (Figure 3).

Then the everted periosteum flap was prepared. The periosteum was incised at the baseline and in the lateral part and was separated from the submucous connective tissue up to the border of the attached gingiva (Figure 4). The crestally pedicled periosteum was everted and transposed coronally where it was fixed with interdental resorbable stitches
(Figure 5). A coronal transposition of the mucoperiosteum was then performed and the mucoperiosteum flap was also fixed with interdental resorbable stitches (Figure 6). Chlorhexidine solution was used twice a day for six weeks after surgery for plaque decontamination.

Clinical follow-up was performed once a week in the first postoperative month, every two weeks in the second postoperative month and once a month thereafter. The clinical examination was repeated 3, 6, and 12 months after surgery, and the results were compared to the preoperative values. In other words, gingival bleeding, attachment loss, and the height of the attached gingiva were examined and compared to the preoperative findings. By comparing the attachment loss mesially, centrally, and distally before and

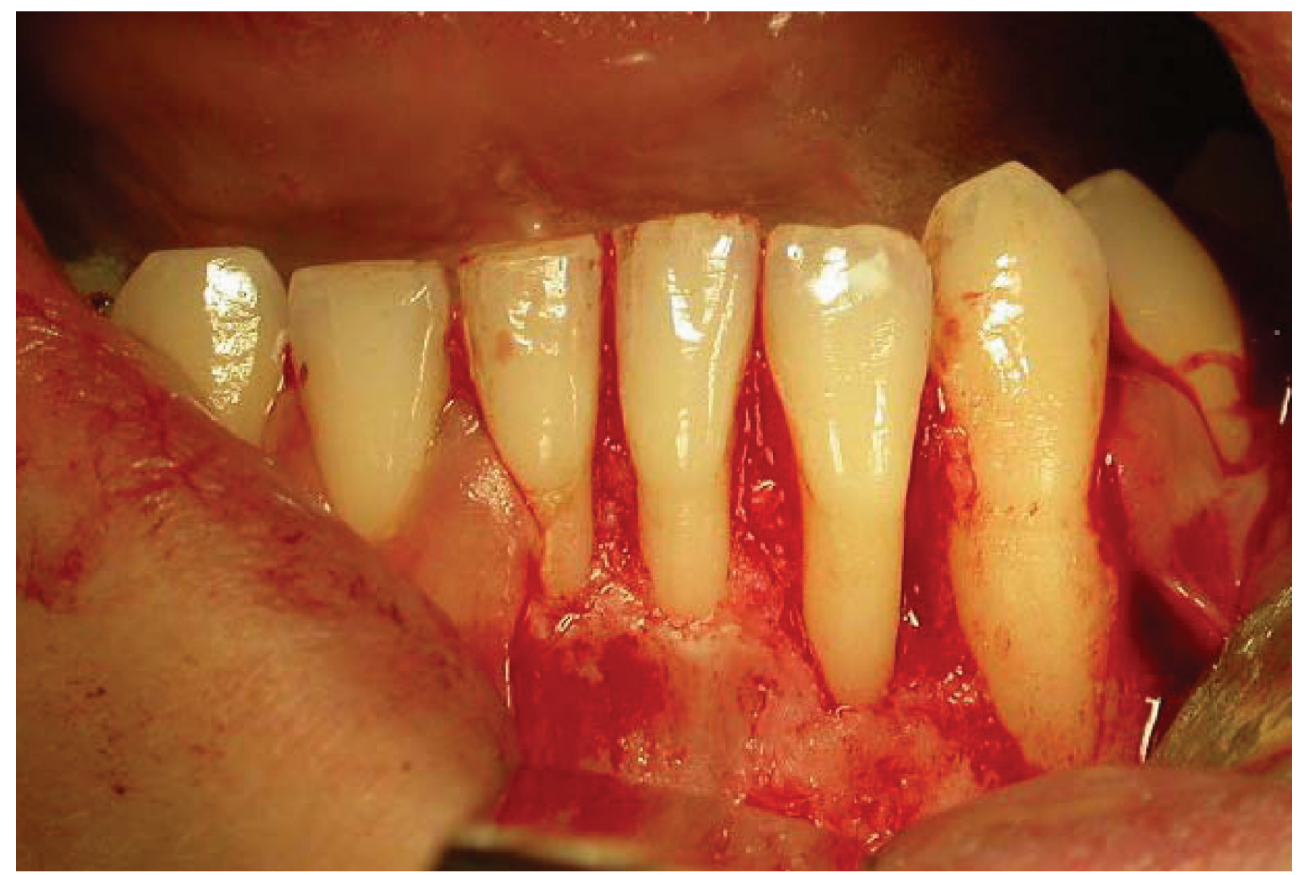

Figure 3 Root surface after washing with physiologic saline solution for $60 \mathrm{~s}$. 


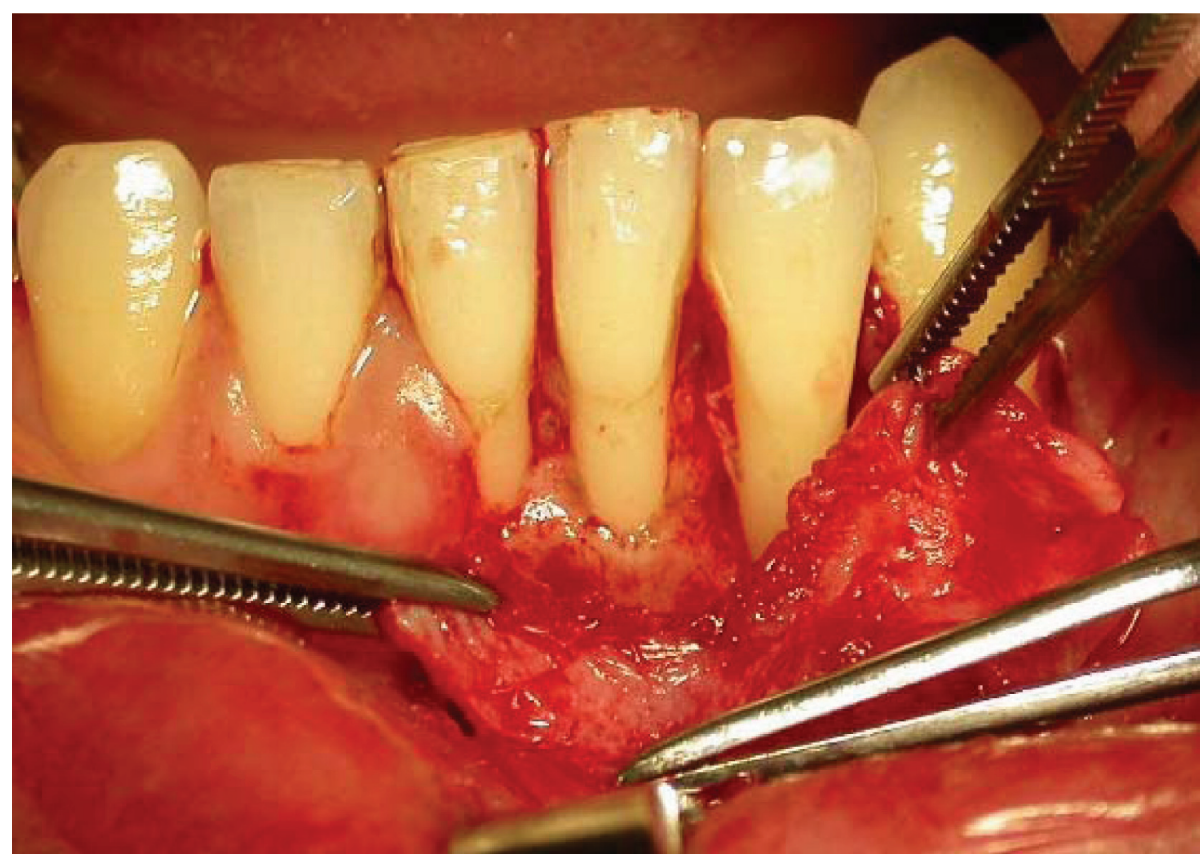

Figure 4 Periosteum incised at baseline and separated from the submucous connective tissue up to the attached gingiva.

after the operation, the percentage of root surface coverage was calculated for each position. The mean percentage of these three values was stated to be the percentage of the whole root coverage.

\section{Results}

Postoperative healing was free of complications in all the patients. Epithelialization of the everted periosteum used for root coverage was seen 14 days after surgery (Figures $7 \mathrm{a}, 7 \mathrm{~b}$ ). An improvement in the clinical situation was seen in all the patients (Figure 7c).

There was no bleeding on periodontal probing at 3,6 , and 12 months postoperatively. The mean periodontal probing depth was $1.2 \mathrm{~mm}$ preoperatively and $0.4 \mathrm{~mm}$ at three and six months postoperatively. Twelve months after surgery, the mean probing depth was $0.3 \mathrm{~mm}(0.1 \mathrm{SD})$.

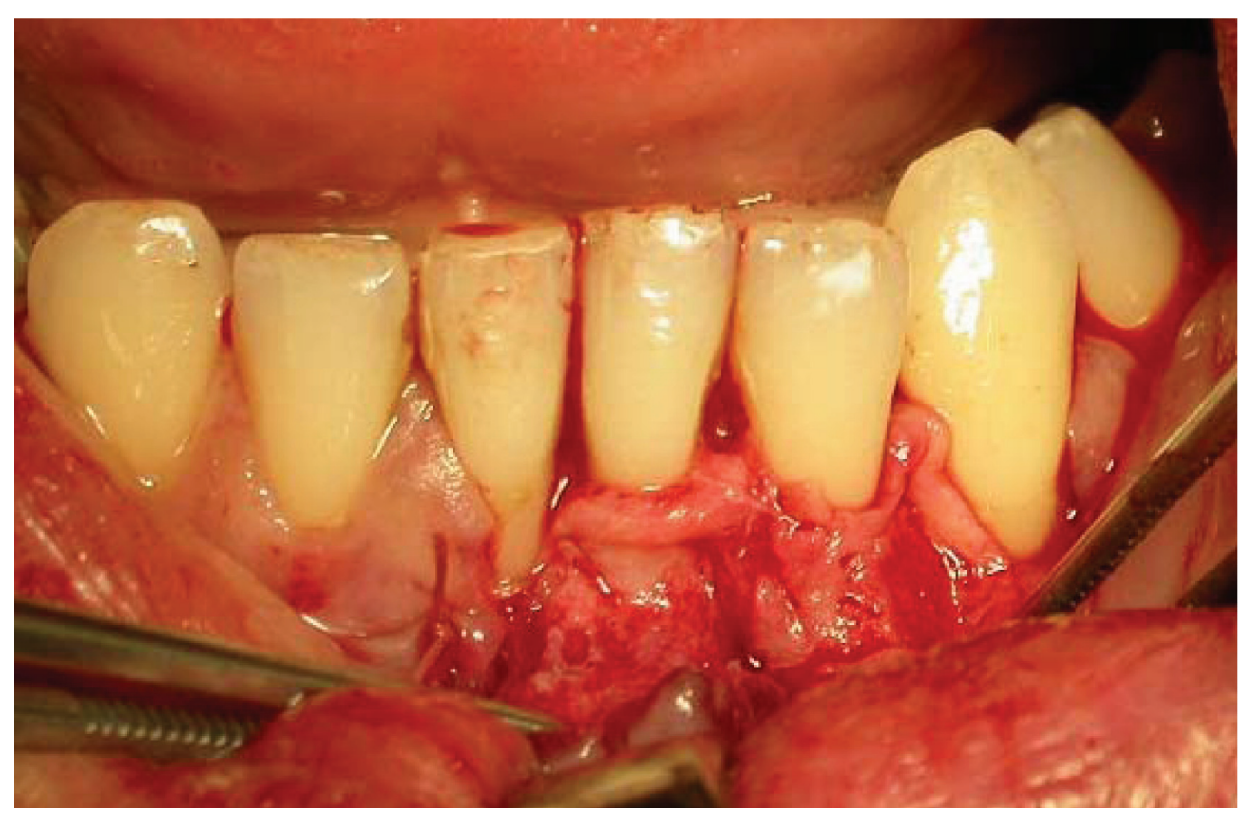

Figure 5 Periosteum after fixing with interdental resorbable stitches. 


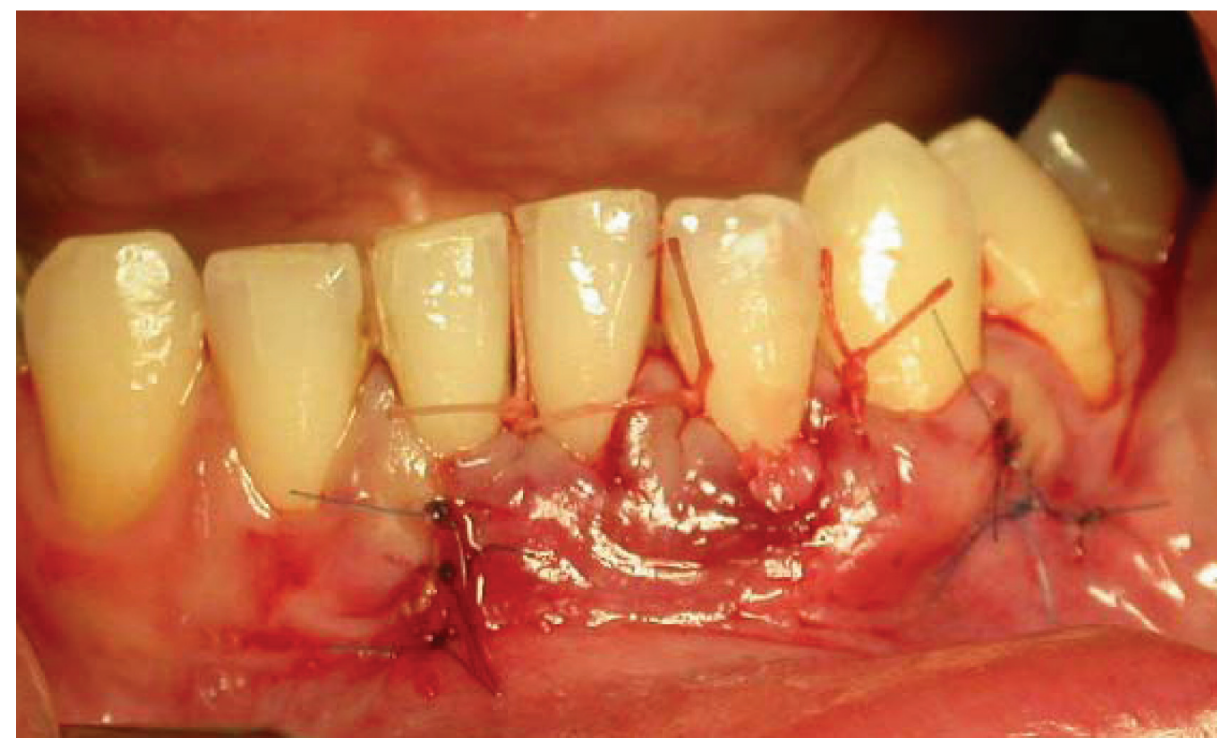

Figure 6 Mucoperiosteum flap after fixing with interdental resorbable stitches.

The mean attachment loss preoperatively was $5.8 \mathrm{~mm}$ (0.2 SD). After three months no attachment loss was registered, while mean values of $0.3 \mathrm{~mm}(0.1 \mathrm{SD})$ were seen at six and 12 months after surgery. There was no attached gingiva in the region of the teeth recession preoperatively. The mean height of attached gingiva was $2.3 \mathrm{~mm}(0.2 \mathrm{SD})$ three months after surgery and $2.2 \mathrm{~mm}(0.1 \mathrm{SD})$ on average at six and 12 months postoperatively. In comparison to the neighbouring teeth, the height of attached gingiva was $0.3 \mathrm{~mm}$ less on average for the surgically treated teeth. The results of the clinical examinations are given in Table 1.

The percentage of root coverage was $100 \%$ at three months postoperatively and therefore complete. A mean value of $94.8 \%$ root coverage was calculated six and 12 months after surgery, which shows a relapse in recession of $5.2 \%$.

\section{Discussion}

The main aim of periodontal surgery is to achieve complete restitution of all periodontal tissue resulting in healthy and aesthetically satisfying periodontal conditions. Covering denuded root surfaces is one of the important goals of surgical periodontal treatment and the best results can be achieved by choosing the most appropriate technique. While small and flat recessions on single teeth can be treated successfully by using surgical flap techniques alone, in the case of large and deep defects with no attached gingiva, the use of free gingiva or connective tissue grafts or membranes becomes more important for achieving the best possible results. ${ }^{36}$ The main advantage of techniques using guided tissue regeneration with membranes (GTR) over techniques using tissue grafts is avoidance of donor site problems. These GTR techniques are used most successfully in periodontal recessions of between 4.5 and $5.5 \mathrm{~mm}$ if keratinized gingiva is still present. ${ }^{5-10}$

Using these techniques, the percentage of root surface coverage is between $60 \%$ and $84 \%$ in a follow-up period of six to 18 months. Medium- and long-term recessions of between 0.75 and $1.7 \mathrm{~mm}$ have been ascertained in the literature.

Table I Clinical data/parameters

\begin{tabular}{lllll}
\hline Parameters & Preoperatively & $\mathbf{3}$ months postop. & $\mathbf{6}$ months postop. & I2 months postop. \\
\hline Plaque accumulation [pos./neg.] & $0 / 30$ & $0 / 30$ & $0 / 30$ & $0 / 30$ \\
Sulcus bleeding [pos./neg.] & $14 / 16$ & $0 / 30$ & $0 / 30$ & $0 / 30$ \\
Probing depths (mean) [mm] & $3.2 \pm 0.3$ & $0.4 \pm 0.1$ & $0.3 \pm 0.1$ & $0.3 \pm 0.1$ \\
Attachment loss (mean) [mm] & $5.8 \pm 0.2$ & $0 \pm 0.0$ & $0.3 \pm 0.1$ & $0.3 \pm 0.1$ \\
$\begin{array}{l}\text { Height of ceratinized gingiva } \\
\text { (mean) [mm] }\end{array}$ & $0 \pm 0.0$ & $2.3 \pm 0.2$ & $2.3 \pm 0.1$ & $2.2 \pm 0.1$ \\
\hline
\end{tabular}




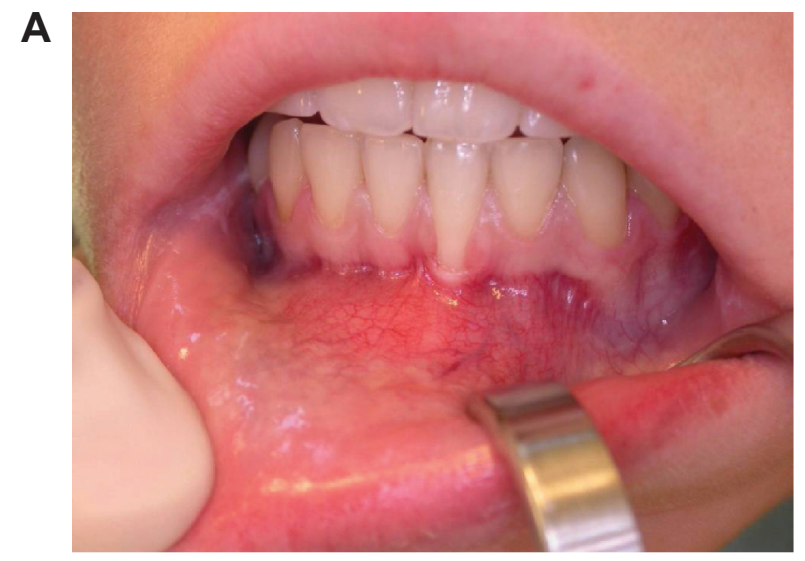

B

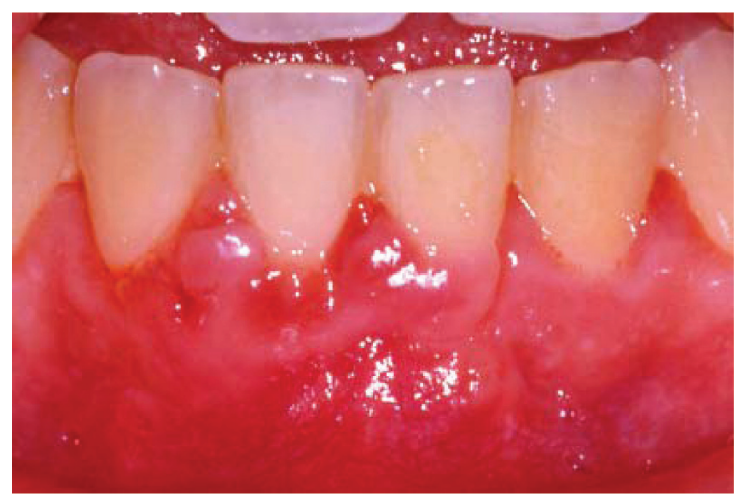

C

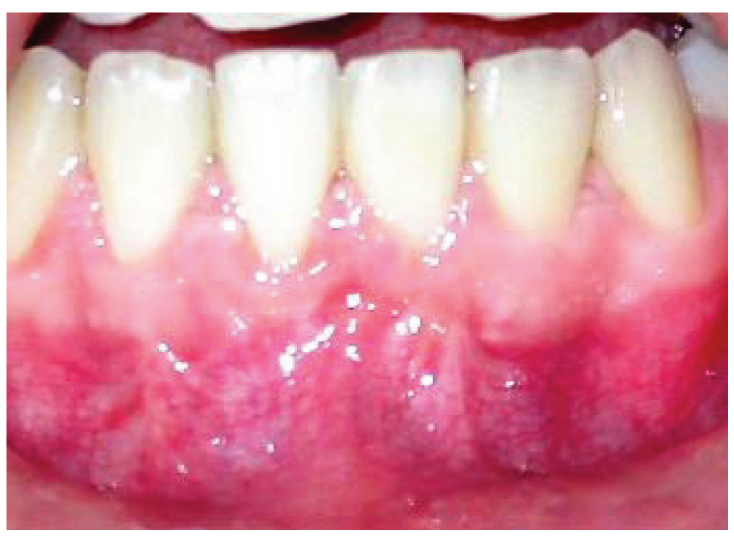

Figure 7 Epithelialization of the root coverage. A \& B, 14 days after surgery. C, after improvement in clinical situation.

The main problem arises if there is wound dehiscence followed by bacterial contamination of the membrane. The defect has to be covered after membrane removal by flap surgery, ${ }^{36}$ which is not successful in every case. Furthermore, GTR techniques are not so successful if there is little or no attached gingiva. In this case, new keratinized gingiva has to be created and other surgical techniques using connective tissue or free gingiva grafts have to be used which bring about a good regeneration of attached gingiva. ${ }^{37,38}$ When using free connective tissue grafts, residual recessions of between $0.1 \mathrm{~mm}$ and $1.27 \mathrm{~mm}$ can be achieved and the percentage of root coverage is between $70 \%$ and $97 \%{ }^{39-47}$ The results vary considerably depending on the surgical techniques used for transplant coverage or preparation and vascularization of the transplant bed. The better the vascularization of the transplant bed, the higher the resulting percentage of keratinized gingiva. ${ }^{38}$ Furthermore it can be assumed that there is a lower extent of root surface coverage when recessions of more than $5 \mathrm{~mm}$ in depth have to be treated. ${ }^{38}$ In these cases, root coverage of between $70 \%$ and $92 \%$ is reported. ${ }^{40,44}$ When comparing combined techniques of graft transplantation and flap surgery, transpositional flaps have better results than the envelope technique. ${ }^{40,44}$

In this study, periodontal recessions of more than $5 \mathrm{~mm}$ were also treated by the new periosteum eversion technique. It was first reported in 2001, and was originally used to cover onlay grafts in augmentative alveolar ridge surgery ${ }^{48}$ and adapted for use in periodontal surgery in this study. The technique is based on using the local periosteum as a vascularized transplant for defect coverage. In comparison to other techniques of periosteum transposition, the periosteum is separated from the mucoperiosteum flap after baseline incision, so that the basal part of the periosteum is used for defect coverage after eversion. The periosteum remains pedicled in the crestal part and can be elongated and coronally transposed without retraction forces. The vascularized periosteum can be used for defect coverage in a similar way to a connective tissue graft and can be epithelialized by the neighbouring mucosa as a vital and well vascularized tissue, although it may not be covered by a mucoperiosteum flap. The principle of tissue regeneration in this new technique is therefore similar to the conventional technique of using connective tissue grafts in combination with a transpositional flap. Therefore the results of periosteum eversion technique should be compared with the results of the conventional technique as described in the literature. In this study the periosteum eversion technique resulted in a rate of defect coverage of $94.8 \%$ and a mean residual denuded root surface of $5.2 \%$ one-year postoperatively. This result is very similar to the results of defect coverage in recessions of between 4 and $6 \mathrm{~mm}$ using a combination of connective tissue grafts and a mucoperiosteum flap and surpasses the results of the envelope technique in this kind of defect. ${ }^{40,44}$ Furthermore the periosteum eversion technique and the combined connective tissue graft and flap technique both show better long-term results for root coverage than GTR techniques for these special defects. When using membrane techniques, the extent of root coverage is between $72.7 \%$ and $82 \%{ }^{49,50}$ 
An improvement in attached gingiva is similar for both the periosteum eversion technique and the combined connective tissue graft and flap technique. ${ }^{50}$ The main advantage of the periosteum eversion technique in comparison to all other techniques using free grafts is that there is no donorsite morbidity. ${ }^{33}$ Although connective tissue grafts are only associated with minor donor site problems, they may only be harvested to a limited extent, ${ }^{51}$ whereas periosteum exists in every location of the alveolar ridge and can also be used for covering multiple recessions in the same patient. Furthermore there is only a low risk of transplant necrosis in well vascularized tissue. ${ }^{4}$ Although the incidence of necrosis is low in free connective tissue grafts, the well vascularized periosteum flap has the possibility to react to bacterial contamination like any other vital tissue and the danger of necrosis and infection in this kind of flap is low. The risk of necrosis and infection is at the lowest if a vascularized graft is used and therefore there is a low risk for graft removal with the associated difficulties of second-flap surgery for defect coverage..$^{52-55}$

It can be concluded that the periosteum eversion technique is highly suitable for covering extended denuded roots caused by recession. The technique is similar to a combined therapy of connective tissue graft and flap transposition. Its main advantage is that the periosteum remains vascularized and there are no donor site problems.

The biological mechanisms of tissue regeneration caused by this technique need to be examined in subsequent studies.

\section{Disclosure}

The authors report no conflicts of interest.

\section{References}

1. Björn H. Free transplantation of gingival propria. Sveriges Tandläkar förbunds Tidning. 1963;22:684.

2. Sullivan HC, Atkins JH. Free autogenous gingival grafts. I. Principles of successful grafting. Periodontics. 1968;6:121-129.

3. Sullivan HC, Atkins JH. Free autogenous gingival graft. III. Utilization of grafts in the treatment of gingival recession. Periodontics. 1968;6:152-160.

4. Nelson SW. The subpedicled connective tissue graft: A bilaminar reconstructive procedure for the coverage of denuded root surfaces. J Periodontol. 1987;58:95-102.

5. Pinti Prato GP, Tinti C, Vincenzi G. Guided tissue regeneration versus mucogingival surgery in the treatment of human buccal gingival recession. J Periodontol. 1992;63:919-928.

6. Trombelli L, Schincaglia G, Chencchi L, Calura G. Combined guided tissue regeneration, root conditioning, and fibrin-fibronectin system application in the treatment of gingival recession: A 15-case report. J Periodontol. 1994;65:796-803.

7. Tinti C, Vincenzi G. Expanded polytetrafluorethylene titanium-reinforced membranes for regeneration of mucogingival recession defects. A 12-case report. J Periodontol. 1994;65:1088-1094.

8. Trombelli L, Schincaglia G, Zangari F. Effects of tetracycline HCL conditioning and fibrin-fibronectin system application in the treatment of buccal recession with guided tissue regeneration. J Periodontol. 1995;66:313-320.
9. Roccuzzo M, Lungo M, Correnie G, Gandolfo S. Comparative study of bioresorbable and a non-resorbable membrane in the treatment of human buccal gingival recessions. J Periodontol. 1996;67:7-14.

10. Roccuzzo M, Buser D. Treatment of buccal gingival recession with e-PTFE membranes and miniscrews: surgical procedure and results of 12 cases. Int J Periodontics Restorative Dent. 1996;16:357-365.

11. Norberg O. Är en utläkining utan vävnadsförlust otänkbar vid kirkurgisk behandling av s.k. alveolarpyorrea? Svensk Tandläkar Tidskrift. 1926;19:171-172.

12. Allen EP, Miller PD. Coronal positioning of existing gingiva: Short term results in the treatment of shallow marginal tissue recession. J Periodontol. 1989;60:316-319.

13. Grupe HE, Warren RF. Repair of ginigival defects by a sliding flap operation. J Periodontol. 1956;27:92-95.

14. Pennel BM, Higgison JD, Towner TD, King KO, Fritz BD, Salder JF. Oblique rotation flap. J Periodontol. 1965;36:305-309.

15. Cohen D, Ross S. The double papillae flap in periodontal therapy. J Periodontol. 1968;39:65-70.

16. Patur B. The rotation flap for covering denuded root surfaces: A closed wound technique. J Periodontol. 1977;48:41-44.

17. Raetzke PB. Covering localized areas of root exposure employing the envelope technique. J Periodontol. 1985;56:397-402.

18. Tarnow DP. Semilunar coronally repositioned flap. J Clin Periodontol. 1986;13:182-185

19. Bahat O, Handelsman M, Gordon J. The transpositional flap in mucogingival surgery. Int J Periodontics Restorative Dent.10:473-482.

20. Summer CF. Surgical repair of recession on the maxillary cuspid: Incisally repositioning of the gingival tissue. J Periodontol. 1969;40:119-121.

21. Bernimoulin JP, Lüscher B, Mühlemann HR. Coronally repositioned periodontal flap. J Clin Periodontol. 1990;2:1-13.

22. Langer B, Langer L. Subepithelial connective tissue graft technique for root coverage. J Periodontol. 1985;56:715-720.

23. Langer $L$, Langer $B$. The subepithelial connective tissue graft for treatment of gingival recession. Dent Clin North Am. 1993;37:243-264.

24. Mlinek A, Smukler H, Buchner A. The use of free gingival grafts for the coverage of denuded roots. J Periodontol. 1973;44:248-254.

25. Smukler H. Laterally positioned mucoperiosteal pedicle grafts in the treatment of denuded roots; A clinical and statistical study. J Periodontol. 1976;47:590-595.

26. Caffesse RG, Alspach SR, Morrison EC, Burgett FG. Lateral sliding flaps with and without citric acid. Int J Periodontics Restorative Dent. 1987;7:43-57.

27. Caffesse RG, Espinel MC: Lateral sliding flaps with free gingival graft technique in the treatment of localized gingival recessions. Int $J$ Periodontics Restorative Dent. 1981;1:22-29.

28. Levine RA: Covering denuded maxillary root surfaces with a subepithelial connective tissue graft. Compend Contin Educ Dent. 1991;12:568-577.

29. Bouchard P, Etienne D, Ouhayoun JP, Nilveus R. Subepithelial connective tissue grafts in the treatment of gingival recessions: A comparative study of 2 procedures. J Periodontol. 1994;65:929-936.

30. Wildermann MN, Wentz FM. Repair of dentogingival defects with a pedicled flap. J Periodontol. 1965;36:218-231.

31. Caffesse RG, Kon S, Castelli WA, Nasjleti CE. Revascularization following the lateral sliding flap procedure. J Periodontol. 1984;55:352-358.

32. Gottlow J, Karring T, Nyman S. Guided tissue regeneration following treatment of recession-type defects in the monkey. J Periodontol. 1990;61:680-685.

33. Gottlow J, Nyman S, Karring T, Lindhe J. Treatment of localized gingival recessions with coronally displaced flaps and citric acid: An experimental study in the dog. J Clin Periodontol. 1990;13:57-63.

34. Miller PD Jr. A classification of marginal tissue recession. Int $J$ Periodontics Restorative Dent. 1985;5:8-13.

35. Lange DE. Die gezielte Vorbehandlung vor der systematischen Parodontalbehandlung. Zahnärztliche Welt und Reform. 1975;8:366-374.

36. Sato N. Plastische Parodontalchirurgie in Parodontalchirurgie: Klinischer Atlas. Berlin Quintessenz Verlags GmbH; Germany; 2002;337-447. 
37. Tal H, Moses O, Zohar R, Meir H, Nemcovsky C. Root coverage of advanced gingival recession: a comparative study between acellular dermal matrix allograft and subepithelial connective tissue grafts. J Periodontol. 2002;73:1405-1411.

38. Harris RJ. Connective tissue grafts combined with either double pedicled grafts or coronally positioned pedicled grafts: results of 266 consecutively treated defects in 200 patients. Int J Periodontics Restorative Dent. 2002;22:463-471.

39. Raetzke PB. Covering localized areas of root exposure employing the envelope technique. J Periodontol. 1885;56:397-402.

40. Nelson SW. The subpedicled connective tissue graft - A bilaminar reconstructive procedure for the coverage of denuded root surfaces. J Periodontol. 1987;58:95-102.

41. Paolantonio M. Treatment of gingival recessions by combined periodontal regenerative technique, guided tissue regeneration, and subpedicled connective tissue graft: A comparative clinical study. J Periodontol. 2002;73:53-62.

42. Harris RJ. The connective tissue and partial-thickness double pedicle graft: A predictable method of obtaining root coverage. J Periodontol. 1992;63:477-486.

43. Jahnke PV, Sandifer JB, Gher ME. Thick free gingival and connective tissue autografts for root coverage. J Periodontol. 1993;64:315-322.

44. Allen AL. Use of the subperiosteal envelope in soft tissue grafting for root coverage. II. Clinical results. Int J Periodontics Restorative Dent. 1994; 14:303-315.

45. Harris RJ. The connective tissue with partial-thickness double pedicle graft: The result of 100 consecutive treated defects. J Periodontol. 1994;65:448-461.

46. Bouchard P, Etienne D, Ouhayoun JP, Nilveus R. Subepitheial connective tissue graft in the treatment of gingival recessions. A comparative study of 2 procedures. J Periodontol. 1994;65:929-936.
47. Borghetti A, Louise F. Controlled clinical evaluation of the subpedicled connective tissue grafts for the coverage of gingival recession. J Periodontol. 1994;65:1107-1112.

48. Triaca A, Minoretti R, Merli M, Merz B. Periosteoplasty for soft tissue closure and augmentation in preprosthetic surgery: a surgical report. Int J Oral Maxillofac Implants. 2001;16:851-856.

49. Müller HP, Stahl M, Eger T. Failure of root coverage of shallow gingival recessions employed by GTR and a bioresorbable membrane. Int J Periodontics Restorative Dent. 2001;21:171-181.

50. Kassab MM, Cohen RE. Treatment of gingival recession. J Am Dent Assoc. 2002;133:1499-1506.

51. Fowler EB, Breault LG. Root coverage with an acellular dermal allograft: a three-months case report. J Contemp Dent Pract. 2000;15: 47-59.

52. Urbani G, Graziani A, Lombardo G, Caton JG. Clinical results with exposed polyglactin 910 resorbable membranes for guided tissue regeneration. Int J Periodontics Restorative Dent. 1997;17:40-46.

53. Lekovic V, Klokkevold PR, Kenney EB, Dimitrijelic B, Nedic M, Weinlander M. Histologic evaluation of guided tissue regeneration using 4 barrier membranes: A comparative furcation study in dogs. J Periodontol. 1998;69:54-60.

54. MacDonald ES, Nowzari H, Contreras A, Flynn J, Morrison J, Slots J. Clinical and microbiological evaluation of a bioabsorbable and a nonresorbable barrier membrane in the treatment of periodontal intraosseous lesions. J Periodontol. 1998;69:445-451.

55. Zucchelli G, Cesari C, Clauser C, DeSantis M. Early bacterial accumulation on guided tissue regeneration membrane materials. An in vivo study. J Periodontol. 1998;69:1193-1198. 